\title{
Islamic Religious Education Based on Life Skills Metro City Public High School
}

\author{
Abdul Mujib $^{1}$, Khoirurrijal ${ }^{2}$, Agus Sujarwo ${ }^{3}$, Yuyun Yunita ${ }^{4}$, Umi Kulsum $^{5}$ \\ ${ }^{1,2}$ Institut Agama Islam Negeri Metro \\ ${ }^{3,5}$ Institut Agama Islam An Nur Lampung \\ ${ }^{4}$ Universitas Islam Negeri Raden Intan \\ Email: abdulmujib@metrouniv.ac.id ${ }^{1}$,khoirurrijal@yahoo.com², agussujarwo@yahoo.com³, \\ azkianaziha4@gmail.com ${ }^{4}$, umikulsum@gmail.com ${ }^{5}$
}

\begin{abstract}
Education does not only teach or transform knowledge and skills as well as a sense of culture or religion, education should be able to equip students to be able to solve the problems they face, both now and in the future. The challenge of education in general is not a stand-alone problem, but is related to the development of science and technology and other aspects of life, be it economic, political or socio-cultural. The purpose of the school is to help and direct students in applying Islamic guidance, be able to read the Alquran, love the country, have the ability to have academic skills, proficiency in the computer field. The research approach used is a qualitative research approach, which describes the value of changes that cannot be expressed in numbers. Meanwhile, the key informants were the Principal and Deputy Head of Scholl section of the Curriculum. The researcher focuses on the Development of Life Skill Education based on Islamic Religious Education, which contains components such as; Lifelong learning or continuous learning skills, complex thinking or reading, writing, calculating skills, being able to communicate effectively, being able to collaborate or collaborating and having the ability to work and develop character / ethics or morals (spiritual, sense and emotional), then the researcher translates this into research indicators
\end{abstract}

Keyword: Life Skill;islamic religius; culture or religion

\section{Introduction}

Islamic religious education has become a very significant discussion in the recent era, considering that the current Islamic religious education is no longer able to provide new nuances to students as the successor to the ideals of Islam and the nation, many hope that there will be a review of Islamic education. This review is not only aimed at perfecting the perceived deficiencies, but mainly as an attempt to reexamine aspects and the education system which are oriented towards the formulation of new goals, namely increasing devotion to God Almighty, intelligence, skills and enhancing character. Given that the object of education is human, then man has a responsibility to God Almighty, himself, society and the environment. In this case humans are beings endowed with intelligence, talents, and abilities.

Education does not only teach or transform knowledge and skills as well as a sense of (culture) or religion, education should be able to equip students to be able to solve the problems they face, both now and in the future. In other words, education must be oriented towards the future. As revealed by Umar bin Khattab "Educate your children. Verily they were born for a different era from yours". Islamic education is the transinternalization of Islamic knowledge and values to students through teaching, habituation, supervision and development of its potential in order to achieve harmony and perfection of life in the world and beyond. Islamic education is also an effort or process, seeking, forming, and developing attitudes and behaviors to seek, develop, maintain, and use science and technology or skills for the benefit of humans in accordance with Islamic teachings. Therefore, in essence, the process of Islamic education is a process of preserving and perfecting Islamic culture which always develops in a process of continuous cultural transformation of the 
constant of Revelation which is a universal value.

The concept of Islamic education offers many virtues, among others, because it comes from scientific truth (revelation), which covers all aspects of human life, which is universal, and is not limited to certain nations, and is valid throughout the ages. And this spirit is very in accordance with the nature of humanity, even preparing the development of human instincts so that true happiness is achieved. One of the social problems in various big cities is the growing number of street children which has recently become increasingly worrying. In Jakarta alone, the number of street children used to be only around three thousand people, but in 2011 the number of street children became five times more. Meanwhile, reported Erwin Siregar from the Indonesian Street Children Community (ISCC) Batam, on the island of Batam the population of street children is also growing very fast. If in early 1998 the population was only around 150-200 people, in the second month of 1999 it had increased to 500-600 people.

According to the government's official explanation, the number of street children in various big cities in the country has now reached more than 50,000 people. The accuracy of this figure is actually debatable, because there is a strong impression that it does not take into account the development of the economic crisis which began to have an impact since July 1997. Based on the prediction of the Ministry of Social Affairs, in 1997 alone it was estimated that there were approximately 50,000 children who spent their productive time on the streets. So if it is seen in each region the number of street children in the past year is predicted to increase four to five times from the previous number, it is not impossible that the number of street children in Indonesia today has increased to around 100,000150,000 people, or maybe even more. .

According to Wahono, the high dropout rate and grim job prospects are not just rumors. Statistical data on the unemployment rate shows the sad fate of the nation's hopeful generation, the largest number of unemployed people from year to year is general and vocational high school graduates. From 2005-2010 the range was between 2,106,182 people to 2,886,216 people. The latest in 2012 increased to $3,208,102$ people. Islamic education, which is one of the components in national education, should take part in the various problems of the nation as mentioned above, but these problems have not been able to be seriously answered. This is because Islamic education only pays attention to the cognitive aspects of the growth of awareness of religious values, and neglects the fostering of affective and conative and volative aspects, namely the will and determination to practice religious values. Islamic education should function as a tool for change, innovation and development through new knowledge and skills and training productive human forces to find social and economic change.

Towaf has observed the weaknesses of Islamic education in schools, including the following: 1. The approach tends to be normative. 2. The designed curriculum offers a minimum of competencies. 3 . Implementation tends to be monotonous, and 4. Limited facilities / infrastructure. As a result of these weaknesses students do not live up to religious values as a daily living value, because the presentation of norms is often without an illustration of the existing socio-cultural context. The problem is reinforced by Mochtar Buchori "The failure of Islamic education is caused by educational practice only pays attention to cognitive aspects alone and fostering affective aspects is less attention. "

The challenge of education in general is not a stand-alone problem, but is related to the development of science and technology and other aspects of life, be it economic, political or socio-cultural. Therefore, the implementation of Islamic education is required to be able to answer and anticipate these challenges. Based on this, it becomes logical if Islamic education that has been 
running so far needs to be reviewed, namely education that is oriented to Life Skills, so that it is able to provide alternative educational program services that are able to provide life skills for students. . The life skills education policy programmed by the Ministry of National Education needs to get the attention of a number of related parties, especially for education providers, assistants and developers, as stated in Law Number 2 of 1989 article 1 paragraph 1 concerning the National Education System. conscious to prepare students through guidance, teaching and or training for their role in the future ". Life skills education is needed to prepare students with life skills, both to manage and control themselves to interact in the school and community environment as well as skills to work which can be used as a source of livelihood. Because life skills education is education that is oriented towards life skills, so that students have the courage to face life problems naturally without feeling depressed, then creatively find and be able to overcome them. By providing personal skills, social skills, academic skills and vocational skills that run synergistically and are holistic.

\section{Research Method}

The research approach used is a qualitative research approach, which describes the value of changes that cannot be expressed in numbers. Meanwhile, the key informants were the Principal and Deputy Head of Scholl section of the Curriculum. The method chosen is the card filing system with the cut-up and put in folders appoach approach. To obtain the selection of files, the folders are marked with certain signs to help facilitate the researchers' memory. Data grouping was carried out simultaneously by organizing through coding categories. The development of the coding category system was carried out in two stages, namely: (1) tracing the data to see if there were possible regularities in findings or topics that included data. (2)
Take notes on words or phrases to display the theme or topic. Data grouping was carried out simultaneously by organizing through coding categories. The development of the coding category system is carried out in two stages, namely: (1) Tracing the data to see if there are possible regularities in findings or topics that include data. (2) Take notes on words or expressions in order to display the theme or topic.

\section{Result}

The researcher focuses on the Development of Life Skill Education based on Islamic Religious Education, which contains components such as; Lifelong learning or continuous learning skills, complex thinking or reading, writing, calculating skills, being able to communicate effectively, being able to collaborate or collaborating and having the ability to work and develop character / ethics or morals (spiritual, sense and emotional), then the researcher translates this into research indicators. Next I present the results of the observations at SMA N Kota Metro. In its development, SMA N Kota Metro stands to have the purpose of this school is based on current developments and stated in the curriculum of SMA N Metro City. As a note, in curriculum development activities in the educational process, things that need to be considered are: first, the philosophy of life of the nation, schools and teachers themselves; second, is consideration of the expectations, needs and demands of the community for educational products; third, curriculum conformity with the conditions of students; fourth, the advancement of science and technology is something that cannot be denied to be considered in the process of developing a kirikulum. Along with the above statement, here I convey the essence of the interview excerpt with The purpose of the school is to help and direct students in applying Islamic guidance, be able to read the Alquran, love the country, have the ability to have academic skills, 
proficiency in the computer field. Students are required to choose school extracurricular activities that support their non-academic abilities, including; Computer, English, or other skills to support their communication skills. School objectives lead to the application of student skills, both worship skills and proficiency in information and technology, this is in accordance with the results of interviews with "IT (Faith Taqwa or Information and Technology), high school graduates are at least orderly in worship and can be computers" To develop a school into a school that gets the heart of the community, there needs to be a breakthrough that leads to the achievement of the skills possessed by students, so that they are able to compete with public schools located around Metro City, East Lampung and those in big cities such as Kodya Metro or Bandar Lampung. This can be felt by some students who continue to pursue higher education, such as at IAIN Metro, UM Metro and at UIN Raden Intan and UNILA Bandar Lampung. At the beginning of the new school year all components of the school hold a meeting to discuss the design of the school program, this is held because it is very important to unify the vision, mission and goals of the school. This was stated by the Principal of SMA N Kota Metro in an interview. Islamic religion-based life skills education has been a dream since this college was founded. Teachers of Islamic Religious Education have the responsibility so that these ideals are realized, in line with the educational goal of "upholding and upholding the orders of the Islamic religion so that a true Islamic society can be realized". To realize school programs related to Islamic religionbased proficiency education, schools through Islamic Religious Education teachers design programs that focus on students, especially on school rules and school regulations for improvement in the field of worship and Islamic IT. Following are excerpts of the interview with the Class XI Islamic Education Teacher.
"Islamic studies students worship orderly and are fluent in reading Al-quran, provide studies of Islamic theory so that they understand Islam. Continuous learning skills (lifelong) are skills that are taught, trained by the teacher regularly and continuously and continue to increase and hence students can develop or discover new things from that being taught. The following is an excerpt from the interview of the XII IPA class students of SMA N Metro City who last year represented Metro City in the City-level National Science Olympiad.

Computer learning continuously (continuously) can produce achievements both at the city and provincial levels. The self-confidence of students is much more enhanced if they are taught in certain fields and continuously. The following is an excerpt from the interview, schools are getting more advanced and in the future become Faforit schools in Metro. School graduates are expected to have functional reading and writing skills, both in Indonesian and in a foreign language, for example English and Arabic. The following is an excerpt of the interview for class XI IPA students, Engglis Club has done a lot to change the way English is read and written the habits of students in taking extras certainly cannot be separated from the support of the subject teacher, so that in learning to write, counting and reading they can carry out well. The following is an excerpt of the interview for class XI IPA students. Reading skills understand and interpret written information in the verses of the qur'an, newspapers, magazines, journals and documents, writing communicates thoughts, ideas, information and written messages and makes documents such as letters, directions, guidance, work guidelines, manuals, reports, charts and flow charts. SMA $\mathrm{N}$ Kota Metro implements an obligation for students to read the qur'an and interpret and recite the interpretation of "Ibnu Katsir" every day from 07.00 WIB to 07.30 WIB guided by Islamic Religious Education educators at 
school before the first hour starts, this is It is possible for students to understand from what they read, here are excerpts from the interview from the Islamic Education Teacher Guiding and directing students to carry out routine reading tasks is not a picture case, however, this study can be an interesting concern to be applied in other schools. Counting skills, the basic ability to count and solve practical problems, by choosing the right from the existing mathematical techniques, with or without the help of technology. A study concluded that communication weaknesses will hinder one's personal and professional development. Even business people predict that communication weaknesses will increase their business financing due to mistakes made. Given that the era of globalization has rolled on, the students' mastery of one of the foreign languages (English, French, Arabic, Japanese, German, Mandarin, etc.) is a necessity. Excerpt of interview with "At SMA N Kota Metro, I meet a teacher who teaches English as well as a friendly person, so every Thursday there is an extracurricular activity"

The extracurricular program at school which has many enthusiasts, one of which is the English Language Club, since 2 years it has given the importance of improving student abilities, however, the lack of supporting facilities, for example the language laboratory, has resulted in the achievement that has not been maximized. This is based on an interview with increase the competence of science that I get, and increase understanding This can be proven by the 70 participants who took part in the competition held by STAIN Jurai Siwo SMA N Metro City which was only able to rank 13th, so it takes hard work to compete with schools in big cities. Considering that human life is largely influenced by thinking, students need to be provided with basic provisions and exercises in the right way regarding deductive, inductive, scientific, critical, rational, lateral, systems, creative, explorative, decision-making thinking skills. , and problem solving. Basically, the soul is an amalgamation of faith, taste, emotion, and reason. The soul is a source of strength and control for every human being in solving every problem at hand. In fact, the pros and cons of a nation are greatly influenced by the good and bad hearts of the nation concerned. The erosion of the heart will have a very powerful effect because no matter how high a person's thinking level is, but if it is not based on good moral, spiritual and emotional wellbeing, only destruction will occur. For that, students need to be provided with basic provisions and exercises in the right way regarding moral, emotional and spiritual skills. Integrity, honesty, solidarity, compassion for others, politeness, selfdiscipline, respect for others, human rights, care, tolerance and responsibility. Excerpt from interview with very concern with family friends who come to save their mother. Implementation of Health Management Skills Learning.

Humans were created by Him with the highest dignity so that the person concerned must maintain his own health better than taking care of his belongings. Therefore, students should be provided with basic provisions on body health management so that they have excellent body health, disease-free, and have strong body resistance. Exercising regularly, eating nutritious and taking vitamins, maintaining cleanliness, and getting adequate rest are education skills in managing body health that must be applied in the lives of students. Development of Life Skills (Life Skill) is the ability or skills to develop or maintain life. Life skills development really needs to be developed in learning because it can be the next learning experience. Life skills are education that provides basic provisions and exercises that are carried out correctly to students about the values of daily life so that they are able, capable, and skilled to live their lives, namely to maintain their survival and development in the future. come. Because life skills are abilities, abilities, and skills needed by a person to 
live a life of joy and happiness, and to be able to solve life and life problems without any pressure. Islamic Religious Education is the transinternalization of Islamic knowledge and values to students through teaching, habituation, supervision and development of its potential in order to achieve harmony with the perfection of life in the world and the intellect. Given some of the above and based on the results of data collection through interviews and observations, data is obtained that lead to the development of life skills based on Islamic religious education in SMA N Kota Metro. Thus the researcher will explain in this discussion: God equips humans with various basic tools and potentials known as fitrah which must be actualized and or developed in real life through the educational process itself. The understanding of education in this case is not only limited to a very narrow space, namely school, but education that lasts a lifetime and is carried out in a very wide space, namely the scope of the family, school and community. Therefore education is not only the responsibility of certain institutions, in this case the government, but education is a shared responsibility between the family and the government. In Islam itself, talking about the nature of man will lead to a potential full of developmental phenomena, namely: Psychological and pedagogical potential that influences humans to become qualified personalities to hold the noble rank of other God's creatures. Potential for the development of human life as a caliph on earth that is dynamic and creative and responsive to the surrounding environment. In the first subject of this discussion, the researcher sees that there is a potential that must be moved towards the internal school, namely the Management of SMA N Metro City School must create a social school condition by: 1 . The school equips teachers who are unified and certified cadres who are really concerned about advancing the school and observant of the development of Islamic science and technology. 2.
Conducting trainings for extracurricular skills and tutors. 3. Comparative study of schools that have the same vision and mission as well as school goals in order to find weak points which can then be improved. 4. Pay attention to the financial side (honorarium) of teachers and supervisors in order to create a good and dynamic work atmosphere. Meanwhile, in terms of the school curriculum, there are several things that need attention, including:

a) Education for all, that is, all students must receive the same treatment, obtain lessons so that they have the opportunity to achieve scientific competences in accordance with curricular boundaries, and have a base of skills or skills according to their interests, and according to their needs. b) Providing skills or skills in accordance with the latest technological advances because the market demands that every workforce has the skills to use modern technology tools, global communication skills, mathematics and the ability to access knowledge.

c) Emphasis on cooperation, which emphasizes the experience of students in collaborating with others, through group assignments in the learning process, so that they have the experience of developing the cooperation needed when going into the community.

d) Development of multiple intelligences, namely students must be given the opportunity to develop multiple intelligence by providing opportunities to develop various skills or skills, so that it is easy to make adjustments when in society e) Integration of educational programs with community service activities, so that they have social sensitivity.

Conceptually Islamic education is as expressed by Muhammad Fadlil al-Jamaly by giving meaning, an effort to develop, encourage and invite humans to be more advanced based on high values and a noble life, so that a perfect personality is formed, both related to reason, feeling, or action, or is a process that leads people to a better life 
and elevates their human status according to their basic abilities (fitrah) and teaching abilities. Life skills-based education when compared with Islamic education, such as personal skills, which include detailed selfknowledge skills into faith as a creature of God Almighty who is required to serve Him and His Khalifah on earth. Caring for character, including love of truth, responsibility and discipline, mutual respect and help and so on as a manifestation of divine values (self awareness) and rational thinking skills (thinking skills); which includes the skills to gather information that can be developed by finding out life's problems. The ability to manage information through thinking potential to solve life problems appropriately. Decision-making skills after going through this thought process. Kecakap solves problems after knowing various problems and finding solutions through this thought process. From this rational thinking skill, it is a development of the intellectual potential that has been given by God to humans. These skills are in line with the word of Allah in the holy book of the Koran which reads: Moses said: God rules the east and the west and what is between them: that is Allah if you use your mind. In surah al-baqarah verse 70 it reads:

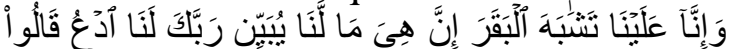

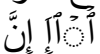

They said: "Ask your Lord for Us so that $\mathrm{He}$ will explain to Us what the nature of the cow is, because Verily the cow is (still) vague for Us and Verily We, God willing, will receive guidance (to obtain the cow)."

It is not wise if the education we provide to students is only limited to developing skills which are only when facing an event. Therefore, a curriculum that is nuanced must be developed but which is based on Islamic religious education. The curriculum in Islamic education must have a group of subjects that are oriented towards the formation of integral personal attitudes and values as citizens and citizens. Academic ability-oriented subject groups and skillsoriented subject groups. The relationship between the school and the community is essentially a tool that is very instrumental in fostering and developing the personal growth of students in school. In this case, school as a social system is an integral part of a larger social system, namely society. Schools and communities have a very close relationship in achieving school or educational goals effectively and efficiently. In this connection, schools can be called human investment institutions. This type of investigation is very important for the development and advancement of society, because man himself is the subject of every development of change and progress in society. So in this case there are four kinds of influences that can be played by schooling education on the development of society in its environment, namely: Educate community life Bringing a virus of renewal for the development of society Giving birth to community members who are ready and equipped for the interests of work in the community and Give birth to positive and constructive attitudes for citizens, so as to create harmonious social integration in the midst of society Through school management carrying out good and harmonious cooperation from the school with parents and the community (education stakeholders) at the policy level and operational level, in order to better understand, assist, be active and control the management of education, it is hoped that it can contribute to improving the quality of Islamic education. overall, so that Islamic education will become quality education that is of interest to students and has a high selling power in the midst of society through the mastery of life skills that students have.

\section{Conclusion}

Life skills education is a new alternative to Islamic education through the development of an Islamic education curriculum. The curriculum contains a variety of life skills, through a balance between theory and practice, or between science and charity in 
everyday life, by identifying life skills on each scientific topic needed. There are several things that are done at SMA N 1 Metro, namely:

1. Monitoring and evaluating student progress

2. Motivating the Success of Students Who Have Achieved

3. Commitment of human resources to the work program of Islamic Religious Education

When the formulation and implementation of school goals is communicated with all parties, it will be carried out optimally and will receive attention and control from the parties involved. Therefore, cooperation with all school components is urgently needed in implementing school work programs so that it is synergistic and sustainable, creates kodusifitas among all school members and gives full trust to all parts.

The school's efforts in developing life skills education based on Islamic religious education include starting from noon to entering the morning, educators who are on average S. 1 and S. 2 and some teachers who are currently taking S.2 and some even continue their doctorate. The most interesting thing is that the various school programs lead to advanced quality skills education and technology, the school has a strong internet network and is supported by the seriousness of young people with qualifications that are passionate about advancing the school. Technology has penetrated all life and is the prime mover of life. Even the superiority of technology is one of the powerful competitiveness factors. SMA N 1 Metro is equipped with an internet network and a computer laboratory which is used for daily student practice. It can be seen in the school schedule for computer lessons to get enough space, if detailed, ICT Subjects include computer theory $=2$ hours, computer practice specifically for MS Office $=2$ hours and plus Computer Club a week of 2 meetings for specifically Graphic Design. So the researchers concluded that this school implements life skills education which leads to a special expertise, namely in the field of computers or information and technology, especially in almost all lessons using computers and the internet, its job is also to use information systems both SMS, Facebook and sending assignments via email. School management faces several problems that hinder the implementation and development of skills education. From a financial point of view, school management must think hard to pay for the feasibility of this program. In terms of the ability of students, school management must recruit educators who truly have proficiency, while what happens is those who have more abilities in certain skill fields usually prefer to live in big cities that promise higher salaries / honoraria. In terms of infrastructure, compared to surrounding schools, schools benefit more from a large area of land and more complete facilities.

\section{Reference}

[1] Anwar. Pendidikan Kecakapan Hidup ( life skills education ), Bandung: Alfabeta. 2012.

[2] Azra, Azyumardi. Pendidikan Islam Tradisi dan Modernisasi Menuju Millennium Baru, Jakarta: Logos Wacana Ilmu. 1999.

[3] Arifin, M. Ilmu Pendidikan Islam. Jakarta: Bumi Aksara, 1996.

[4] Al-Jauzy, bin Ali Hasan. Manhaj Tarbiyah Ibnu Qayyim. Jakarta Timur: Pustaka Al-Kautsar. 2001.

[5] Al-Jamali, Fadlil, Muhamamad. Filsafat Pendidikan Dalam AlQur'an. Surabaya: Bina Ilmu. 1986.

[6] Al-Turabi, Hasan. Fiqih Demokratis: Dari Tradisionalisme Kolektif Menuju Modernisme Populis. Jakarta: Arasy. 2003.

[7] Sugiono. Metode Penelitian Pendidikan : Pendekatan Kuantitatif, Kualitatif dan R\&D. Bandung : Alfabeta, 2010. 
[8] Ali, Mohamammad. Pengembangan Kurikulum di Sekolah. Bandung: Sinar Baru. 1985.

[9] Depdiknas, Tim Broad Based Education. Kecakapan Hidup life Skill Melalui Pendekatan Pendidikan Berbasis Luas, Surabaya: SIC. 2002.

[10]

- Pola Pelaksanaan Pendidikan Kecakapan. Surabaya: SIC. 2003.

[11] Djohar. Pendidikan Strategik: Alternative Untuk Pendidikan Masa Depan. Yogyakarta: LEFSI. 2003.

[12] Daradjat, Zakiyah. Ilmu Pendidikan Islam. Jakarta: Bumi Angkasa. 1996.

[13] Feisal, Amir, Jusuf. Reorientasi Pendidikan Islam. Jakarta: Gema Insani Press. 1995.

[14] Furqan, Arief. Pengantar Metode Penelitian Kualitatif. Surabaya: Usaha Nasional. 1992.

[15] Hitami, Munzir. Mengonsep Kembali Pendidikan Islam. Riau: Infinite Press. 2004.

[16] Hujair dan Sanaky. Paradigma Pendidikan Islam: Membangun Masyarakat Madani Indonesia. Yogyakarta: Safiria Insania Press. 2003.

[17] Kholiq, Abdul dkk. Pemikiran Pendidikan Islam Kajian Tokoh Klasik Dan Kontempore. Yogyakarta: Pustaka Pelajar. 1999.

[18] Langgulung, Hasan.. Beberapa Pemikiran Tentang Pendidikan Islam. Bandung: Al-Ma'arif. 1980

[19] Nata, Abuddin. Metodologi Studi Islam, Jakarta: PT Raja Grafindo Persada, 2001.

[20] Muhaimin. Arah Baru Pengembangan Pendidikan Islam. Bandung: Nuansa. 2003.

[21] Marimba, D. Ahmad. Pengantar Filsafat Pendidikan Islam. Bandung: Al-Ma'arif. 1980.

[22] Moleong, J. Lexy. Metodologi Penelitian Kualitatif". Bandung: PT. Remaja Rosdakarya. 1998.
[23] Muhajir, Noeng. Metodologi Penelitian Kualitatif. Yogyakarta: Rake Surasin. 1989.

[24] Maksum. Madarasah Sejarah Dan Perkembangannya. Jakarta: PT Logos Wacana Ilmu. 1999.

[25] Mulyasa, E. Manajemen Berbasis Sekolah: Konsep, Strategi, dan Implementasi. Bandung: Remaja Rosdakarya. 2003.

[26] Ridla, Jawwad, Muhammad. Tiga Aliran Utama Teori Pendidikan Islam. Yogyakarta: PT Tiara Wacana. 2002.

[27] Rahman, Ali, Nur. Impelentasi CTL dalam Pembelajaran di Madrasah, Makalah disajikan dalam Perkuliahan Jurusan Pendidikan Islam, Fakultas Tarbiyah, UIN Malang.

[28] Sularto, ST. Seandainya Aku Bukan Anakmu. Jakarta: Kompas, 2000..

[29] Soejono dan Abdurrahman. Metode Penelitian Suatu Pemikiran dan Penerapannya. Jakarta: Reneka Cipta. 1999.

[30] Suparno, Paul dkk. Reformasi Pendidikan Sebuah Rekomendasi. Yogyakarta: Kanisius. 2000.

[31] Senduk, Gerrad, Agus dan Nurhadi. Pembelajaran konstektual dalam penerapannya dalam KBK. Malang: Universitas Negeri Malang. 2004.

[32] Soebahar, Halim, Abd.. Wawasan Baru Pendidikan Islam. Pasuruan: PT Garoeda Buana Indah. 1992

[33] Soetopo, Hendyat dan Soemanto, Wasty. Pembinaan dan Pengembangan Kurikulum: Sebagai Subtansi Problem Administrasi Pendidikan. Jakarta: Bumi Aksara. 1993.

[34] Undang-undang Republik Indonesia No 20 Tahun 2003..Bandung: Citra Umbara. 2003

[35] Wahyono, Tekad. Program Keterampilan Hidup (Life Skill Program) Untuk Meningkatkan Kematangan Vokasional Siswa. ANIMA Indonesian Psychological Journal, 2002.. 
[36] Zuhairini, dkk. Metodik Khusus

Pendidikan Agama. Surabaya: Usana

Offset Printing. 1981. 